\title{
The Role for Academics to Play in Advancing Sustainability Integration in Marketing Education and Research: An Abstract
}

\author{
Joya A. Kemper, Paul W. Ballantine, and Michael Hall
}

\begin{abstract}
Past research on how universities integrated sustainability show a large involvement from change agents, which are usually academics themselves; these champions are usually at the forefront of new ideas for EfS. As such, although the literature has explored the role of higher education in sustainability and how to shift to EfS, few studies have paid attention to the role of the individual. It is also only through the experiences of sustainability marketing academics that we can begin to understand what struggles and barriers may exist towards the integration of sustainability within marketing academia and how individuals might address these barriers.
\end{abstract}

References Available Upon Request

\footnotetext{
J. A. Kemper $(\square)$

University of Auckland, Auckland, New Zealand

e-mail: j.kemper@auckland.ac.nz

P. W. Ballantine $\cdot$ M. Hall

University of Canterbury, Christchurch, New Zealand

e-mail: paul.ballantine@ canterbury.ac.nz; michael.hall@canterbury.ac.nz 